\title{
Effect of Feeding of Moringa (Moringa oleifera) Leaf Meal Based Diets on the Biometry and Body Condition Score of Deccani Lambs
}

\author{
S. M. Bhokre ${ }^{1}$, N. Rajanna ${ }^{2}$, D. B. V. Ramana ${ }^{3}$, D. Nagalakshmi ${ }^{4}$, \\ M. Kishan Kumar ${ }^{5}$ and M. Sashi Kumar ${ }^{6}$ \\ ${ }^{1}$ COVAS, Shirwal, MAFSU, Maharastra, India \\ ${ }^{2}$ Department of LPM, College of Veterinary Science, PVNR TVU, \\ Rajendranagar, Hyderabad-30, TS, India \\ ${ }^{3}$ (LPM), ICAR-CRIDA, Santosh Nagar, Hyderabad, TS, India \\ ${ }^{4}$ Department of Animal Nutrition, College of Veterinary Science, PVNR TVU, \\ Rajendranagar, Hyderabad-30, TS, India \\ ${ }^{5}$ (LPM) and OSD, College of Fishery Science, PVNR TVU, Pebbair, Vanaparthy, TS, India \\ ${ }^{6}$ Department of Livestock Products Technology, College of Veterinary Science, PVNR TVU, \\ Rajendranagar, Hyderabad-30, TS, India \\ *Corresponding author
}

\section{A B S T R A C T}

\section{Keywords}

Moringa leaf meal, Deccani lambs,

Biometry and body condition score

Article Info

Accepted:

10 March 2020

Available Online:

10 April 2020
An investigation was carried out to study the effect of feeding Moringa leaf meal-based diets on the biometry and body condition score in Deccani growing lambs. Eighteen growing either sex of lambs with uniform body weights $(14.22 \pm 1.5 \mathrm{~kg})$ and aged between 4 and 8 months were selected for the study and randomly allotted to three treatment groups with six lambs in each group $(6 \times 3)$. Three experimental diets were prepared using 100 per cent groundnut cake (T1), $75 \%$ groundnut cake+ $25 \%$ Moringa oliefera leaf meal (T2) and $50 \%$ groundnut cake+ $50 \%$ Moringa oliefera leaf meal (T3) as protein source in the concentrate mixture and all lambs fed with ad libitum green fodder. The investigation was conducted for 90 days. The fortnightly biometric measurement findings indicated that the mean fortnight body length, face length and hip width of growing Deccani lambs increased linearly throughout the experimental period and body length had a significant difference $(\mathrm{P}<0.05)$ among the treatments while the height at wither, chest girth, face length and tail length showed non-significance difference between the groups. The final body condition score was significant $(\mathrm{P}<0.01)$ among the three treatment groups. Significantly $(\mathrm{P}<0.05)$ higher BCS was observed in T2 group lambs than T1 and T3 group lambs from 3rd to 6th fortnight. Inclusion of Moringa oliefera leaf meal at $25 \%$ in the concentrate mixture improved the biometry and body condition score in lambs reared in intensive farming system. 


\section{Introduction}

As per $20^{\text {th }}$ Livestock Census (2019-20) the sheep population in India is 74.26 million and contributes $13.87 \%$ of the total livestock population. India ranks third in world sheep population with $6.8 \%$ of the world population and contributing to $4.9 \%$ of total meat production in the country. The sheep sector is growing at annual rate of $3.9 \%$ and producing 556.44 (in 000 Tons) of mutton in the country (BAHS, 2016-17).

India's huge small ruminant (sheep and goat) population still sustain to larger extent on the grazing resources, grazing based animal husbandry plays a significant role in rural economy of an agrarian country like India. The grazing activity depends on the availability of the grazing resources from pasture and other grazing lands, viz. forest, miscellaneous tree crops and groves, cultivable waste lands and fallow lands. The requirement for fodder is mainly governed by the population and species of livestock, management level and climate condition. As per estimates of IGFRI (2013) the availability of green fodder from cultivated areas and pastures is 826.0 MT against the demand of 1012.7 MT in the country by 2050 . Similarly, in case of dry fodder, estimated total availability will be 547.7 MT (from dry residues and by-products of grain, commercial crops and dry grass from grazing lands and forests) against the requirement of 631.0 MT. The total area under cultivated fodder is only $8.4 \mathrm{~m}$ ha on individual crop basis which is static since last two decades. The scope for further increase in area under forages seems meagre due to pressure of food crops for human population.

Utilization of fodder trees and shrubs could be a potential strategy for increasing the quality and availability of feeds for resource-limited livestock farmers during the dry season. The trees provide a good and cheaper source of protein and micronutrients (Moyo et al., 2012a). In recent years, there has been increased research on alternative protein sources from forage trees and shrubs that can be fed to sheep. In recent years, attention has been given to the use of moringa leaf meal (MLM) as a protein source and feed component in animal production especially in goats (Sarwatt et al., 2002 and Asaolu et al., 2010) and also for other ruminants (Sarwatt $e t$ al., 2000). In view of this, the present study was planned to replace GNC with dried Moringa oleifera leaf meal in the concentrate mixture of sheep reared under intensive farming system to study the biometry and body condition score.

\section{Materials and Methods}

Eighteen growing Deccani sheep of uniform body weight $(14.19 \pm 1.5 \mathrm{~kg})$ and age (4 to 8 months) were selected and randomly allotted to three treatment groups with six lambs in each group $(6 \times 3)$ and reared in intensive farming at LFC, Rajendranagar. Three experimental diets were prepared using 100 percent groundnut cake (T1), 75\% groundnut cake+ 25\% Moringa oliefera leaf meal (T2) and $50 \%$ groundnut cake+ $50 \%$ Moringa oliefera leaf meal (T3) as protein source in the concentrate mixture and offered as per the ICAR (2013) recommendations along with $a d$ libitum green fodder. The dried leaves were finely grounded to powder form and then bagged and stored for incorporation in the concentrate mixture. The composition of the ingredients in the concentrate mixture shown in the Table 1.

All the lambs in the experiment were provided with a floor space of $1 \mathrm{~m}^{2} /$ lamb in the covered shed with asbestos roof. The experimental lambs were ear tagged for proper recording of the data. All the lambs were dewormed with Albendazole @ 10 mg 
$/ \mathrm{kg}$ body weight before start of the experiment and once in the middle of the trail. Proper feeding and watering arrangements were made hygienically.

Body measurements were recorded by using a standard measuring tape to the nearest 0.5 centimeter after the animals were allowed to stand squarely on an even ground. This was performed in the morning before the animals were fed. The body measurements were recorded as per Narasimham et al., (2003) and Rajanna et al., (2013) as mentioned below.

\section{Height at withers}

Distance from the base of the hoof to the highest point of withers.

\section{Chest girth}

Body circumference around the chest, just behind the elbow joint.

\section{Body length}

Distance from point of shoulder to the point of tuber ischii.

\section{Hip width}

Distance from the tuberosity prominence of ilium bone of one side to the other, across the rump.

\section{Face length}

Distance from the base of the nose to the middle point of head.

\section{Tail length}

Distance from the base of the tail to the head of tail. Body Condition score of the sheep were recorded at fortnightly intervals by visual appraisal and by palpation or combination of the two in sheep. The body condition score was done based on 1 to 5 scale system with an interval range of 0.5 point as per the procedures suggested by Russel et al., (1969). The scores assigned were tallied with score of two colleague researchers and advisor of the research for correction and accuracy.

Statistical analysis of the data was carried out in accordance with Snedecor and Cochran (1994). Analysis of variance was used to test the significance of variance and the treatment means tested for significance by Duncans new multiple range $\mathrm{F}$ test (Duncan,1995).

\section{Results and Discussion}

\section{Biometry of lambs}

The biometric measurements indicate the skeletal growth of the animals. Body length and height at withers are the measures of bony growth while chest girth is a measure of development of muscles, bones and fat and it had close relationship with live weight (Pomeroy, 1955). Effect of feeding experimental diets on biometry in Deccani lambs is present in Table 2.

\section{Fortnightly body length}

The body length was much pronounced from $4^{\text {th }}$ to $6^{\text {th }}$ six fortnight of the experiment in all the animal groups. Statistical analysis revealed a significant difference $(\mathrm{P}<0.05)$ among three treatment groups in final fortnight ( $6^{\text {th }}$ fortnight).

T2 group lambs had significantly $(\mathrm{P}<0.05)$ higher body length than T1 group lambs (Table 2). This could be due to more bony growth and associated weight gain as result of better digestibility of nutrients with efficient utilization of absorbed nitrogen with Moringa leaf supplementation in T2 lambs. 
The results of the present study are comparable with the findings of Bharambe and Burte (2012), Padama Meel (2018) and Jagritisrivastav (2019). In contrast to these results Adegun and Aye (2011) found a significant increase in final body length when sheep was fed with Moringa based multi nutrient blocks.

\section{Fortnightly height at withers}

There was no significant difference $(\mathrm{P}>0.05)$ in height at withers (HW) among the treatment group lambs, however HW was relatively higher in Moringa supplemented group lambs (T2 and T3) when compared to T1 (Table 2). This could be due to more weight gain along with bony growth as result of better digestibility of nutrients with efficient utilization of absorbed nitrogen in T2 and T3 group lambs. These findings are in agreement with reports of Padama Meel (2018) in goat kids fed with Moringa leaves. In contrast to these results Adegun and Aye (2011) found a significant increase in final height at wither when sheep was fed with Moringa based multi nutrient blocks.

\section{Fortnightly chest girth}

The circumference of chest of the animals is an important indicator of animal health, body weight and size and which helps in respiration. The rate of weight gain in terms of body weight and average daily gain was reflected in concomitant growth of chest girth in all the experimental group lambs. The growth of chest girth was much pronounced from fourth to sixth fortnights in all the experimental groups. The observed chest girth values were non-significantly higher in $\mathrm{T} 2$ and $\mathrm{T} 3$ group as compared to $\mathrm{T} 1$ group lambs (Table 2).

This could be due to more weight gain along with bony growth as result of better digestibility of nutrients with efficient utilization of absorbed nitrogen in $\mathrm{T} 2$ and $\mathrm{T} 3$ group diets which received Moringa oliefera leaf meal in their concentrate mixture. Similar findings were reported by Dass (2007), Bharambe and Burte (2012) for chest girth in stall fed systems, whereas, Adegun and Aye (2011) found a significant increase in final chest girth when sheep was fed with Moringa based multi nutrient blocks.

Table.1 Ingredient composition of experimental diet $(\mathrm{kg})$

\begin{tabular}{|l|c|c|c|}
\hline \multicolumn{1}{|c|}{ Ingredients } & Control T1 & T2 & T3 \\
\hline De-oiled rice bran & 29 & 26.7 & 24.5 \\
\hline Moringa Leaves & - & $7.3^{*}$ & $14.5^{*}$ \\
\hline $\begin{array}{l}\text { Ground nut cake } \\
\text { (De-oiled) }\end{array}$ & 20 & 15 & 10 \\
\hline Cotton seed cake & 13 & 13 & 13 \\
\hline Red gram chunni & 35 & 35 & 35 \\
\hline Salt & 01 & 01 & 01 \\
\hline Min.Mix & 02 & 02 & 02 \\
\hline Total & 100 & 100 & 100 \\
\hline Nutritive value (calculated \%) & & & 60.58 \\
\hline TDN & 60.85 & 60.07 & 18.72 \\
\hline \multicolumn{1}{|c|}{ CP } & 19.28 & 19.00 & \\
\hline
\end{tabular}

*25\% and 50\% GNC Protein replaced with Moringa leaves in T2 and T3, respectively 
Table.2 Effect of feeding experimental diets on biometry in Deccani lambs

\begin{tabular}{|c|c|c|c|c|c|}
\hline Fortnight & T1 & $\mathbf{T} 2$ & T3 & SEM & P Vale \\
\hline & \multicolumn{5}{|c|}{ Body length } \\
\hline 1 & $48.83 \pm 1.62$ & $49.50 \pm 2.46$ & $48.00 \pm 1.69$ & 1.074 & 0.86 \\
\hline 2 & $50.41 \pm 1.46$ & $52.00 \pm 2.25$ & $50.33 \pm 1.38$ & 0.963 & 0.75 \\
\hline 3 & $52.50 \pm 1.18$ & $55.00 \pm 1.67$ & $52.83 \pm 1.19$ & 0.788 & 0.39 \\
\hline 4 & $54.83 \pm 1.14$ & $59.33 \pm 1.36$ & $56.33 \pm 1.56$ & 0.867 & 0.91 \\
\hline 5 & $56.83 \pm 1.22$ & $61.83 \pm 0.98$ & $59.00 \pm 1.84$ & 0.905 & 0.06 \\
\hline 6 & $58.66 \pm 1.09^{b}$ & $66.0 \pm 0.82^{\mathrm{a}}$ & $62.00 \pm 1.51^{\mathrm{ab}}$ & 0.965 & 0.02 \\
\hline \multirow[t]{2}{*}{ Over all mean } & $52.79 \pm 1.57$ & $55.95 \pm 2.57$ & $53.57 \pm 2.18$ & 1.205 & 0.56 \\
\hline & \multicolumn{5}{|c|}{ Height at withers } \\
\hline 1 & $55.58 \pm 0.79$ & $56.83 \pm 0.66$ & $56.16 \pm 2.55$ & 1.182 & 0.92 \\
\hline 2 & $56.66 \pm 0.42$ & $57.83 \pm 2.63$ & $57.00 \pm 2.42$ & 1.155 & 0.82 \\
\hline 3 & $58.33 \pm 0.66$ & $59.33 \pm 2.21$ & $58.66 \pm 0.66$ & 1.083 & 0.93 \\
\hline 4 & $59.83 \pm 0.87$ & $60.33 \pm 2.27$ & $59.83 \pm 2.16$ & 1.022 & 0.97 \\
\hline 5 & $61.00 \pm 0.51$ & $62.16 \pm 0.60$ & $62.16 \pm 2.05$ & 0.842 & 0.82 \\
\hline 6 & $63.00 \pm 0.51$ & $65.16 \pm 1.57$ & $63.50 \pm 1.50$ & 0.736 & 0.48 \\
\hline \multirow[t]{2}{*}{ Over all mean } & $58.71 \pm 1.07$ & $59.28 \pm 1.38$ & $58.69 \pm 1.35$ & 0.704 & 0.93 \\
\hline & \multicolumn{5}{|c|}{ Chest girth } \\
\hline 1 & $59.75 \pm 2.98$ & $61.67 \pm 1.17$ & $60.08 \pm 2.49$ & 1.268 & 0.82 \\
\hline 2 & $60.83 \pm 2.63$ & $62.67 \pm 1.17$ & $61.25 \pm 3.58$ & 1.433 & 0.87 \\
\hline 3 & $62.33 \pm 3.58$ & $63.83 \pm 1.54$ & $63.33 \pm 3.16$ & 1.531 & 0.95 \\
\hline 4 & $63.83 \pm 3.93$ & $65.33 \pm 3.05$ & $65.17 \pm 3.05$ & 1.599 & 0.92 \\
\hline 5 & $66.00 \pm 1.47$ & $66.33 \pm 3.11$ & $66.00 \pm 3.99$ & 1.632 & 0.99 \\
\hline 6 & $68.33 \pm 1.46$ & $69.50 \pm 3.22$ & $67.16 \pm 4.04$ & 1.676 & 0.86 \\
\hline \multirow[t]{2}{*}{ Over all mean } & $64.69 \pm 0.98$ & $63.55 \pm 1.44$ & $62.76 \pm 1.16$ & 0.678 & 0.68 \\
\hline & \multicolumn{5}{|c|}{ Hip width } \\
\hline 1 & $11.58 \pm .045$ & $11.90 \pm 0.59$ & $11.08 \pm 0.55$ & 295 & 0.78 \\
\hline 2 & $11.59 \pm 0.55$ & $12.08 \pm 0.52$ & $12.00 \pm .045$ & 0.281 & 0.76 \\
\hline 3 & $12.08 \pm 0.55$ & $12.67 \pm 0.56$ & $12.50 \pm 0.55$ & 305 & 0.74 \\
\hline 4 & $12.58 \pm 0.55$ & $13.08 \pm 0.55$ & $13.03 \pm 0.42$ & 0.288 & 0.58 \\
\hline 5 & $13.09 \pm 0.48$ & $13.75 \pm 0.53$ & $13.17 \pm 0.60$ & 0.299 & 0.68 \\
\hline 6 & $13.16 \pm 0.48$ & $14.42 \pm 0.58$ & $13.83 \pm 0.70$ & 0.345 & 0.35 \\
\hline \multirow[t]{2}{*}{ Over all mean } & $12.41 \pm 0.32$ & $12.76 \pm 0.40$ & $12.11 \pm 0.44$ & 0.222 & 0.52 \\
\hline & \multicolumn{5}{|c|}{ Tail length } \\
\hline 1 & $13.58 \pm 0.93$ & $14.00 \pm 0.61$ & $13.75 \pm 0.68$ & 0.412 & 0.92 \\
\hline 2 & $14.28 \pm .066$ & $14.58 \pm 0.55$ & $14.33 \pm 0.79$ & 0.369 & 0.93 \\
\hline 3 & $14.83 \pm 0.65$ & $16.00 \pm 0.93$ & $15.16 \pm 0.51$ & 0.408 & 0.51 \\
\hline 4 & $15.41 \pm .063$ & $16.40 \pm 1.05$ & $15.75 \pm 0.47$ & 0.428 & 0.6 \\
\hline 5 & $16.00 \pm 0.74$ & $16.50 \pm 1.056$ & $16.33 \pm 0.40$ & 0.426 & 0.9 \\
\hline 6 & $16.41 \pm 0.62$ & $16.83 \pm 0.60$ & $16.56 \pm 1.05$ & 0.393 & 0.88 \\
\hline \multirow[t]{2}{*}{ Over all mean } & $14.85 \pm 0.42$ & $15.24 \pm 0.55$ & $15.17 \pm 0.45$ & 0.266 & 0.83 \\
\hline & \multicolumn{5}{|c|}{ Face length } \\
\hline 1 & $16.91 \pm 0.30$ & $17.15 \pm 0.35$ & $17.05 \pm 0.61$ & 0.241 & 0.92 \\
\hline 2 & $17.33 \pm 0.30$ & $17.75 \pm 0.35$ & $17.63 \pm 0.60$ & 0.242 & 0.79 \\
\hline 3 & $17.75 \pm 0.29$ & $18.85 \pm 0.44$ & $18.06 \pm 0.52$ & 0.247 & 0.48 \\
\hline 4 & $18.35 \pm 0.32$ & $19.33 \pm 0.57$ & $18.41 \pm 0.61$ & 0.301 & 0.35 \\
\hline 5 & $18.75 \pm 0.28$ & $20.00 \pm 0.65$ & $19.08 \pm 0.65$ & 0.329 & 0.29 \\
\hline 6 & $19.33 \pm 0.24$ & $20.75 \pm 0.65$ & $20.58 \pm 0.65$ & 0.334 & 0.18 \\
\hline Over all mean & $18.01 \pm 0.33$ & $18.53 \pm 0.60$ & $18.06 \pm 0.43$ & 0.205 & 0.62 \\
\hline
\end{tabular}

Mean with different superscripts row wise indicate significant difference $(\mathrm{P}<0.05)$ 
Table.3 Effect of feeding experimental diets on body condition score in Deccani lamb

\begin{tabular}{|c|c|c|c|c|c|}
\hline Fortnight & T1 & T2 & T3 & SEM & P Vale \\
\hline $\mathbf{1}$ & $2.22 \pm 0.03^{\mathrm{b}}$ & $2.92 \pm 0.15^{\mathrm{a}}$ & $2.67 \pm 0.11^{\mathrm{a}}$ & 0.092 & 0.00 \\
\hline $\mathbf{2}$ & $2.25 \pm 0.02^{\mathrm{b}}$ & $3.17 \pm 0.10^{\mathrm{a}}$ & $3.00 \pm 0.12^{\mathrm{a}}$ & 0.110 & 0.001 \\
\hline $\mathbf{3}$ & $2.32 \pm 0.03^{\mathrm{a}}$ & $3.42 \pm 0.08^{\mathrm{c}}$ & $3.08 \pm 0.15^{\mathrm{b}}$ & 0.125 & 0.00 \\
\hline $\mathbf{4}$ & $2.4 \pm 0.03^{\mathrm{a}}$ & $3.58 \pm 0.08^{\mathrm{c}}$ & $3.33 \pm 0.11^{\mathrm{b}}$ & 0.131 & 0.002 \\
\hline $\mathbf{5}$ & $2.48 \pm 0.03^{\mathrm{a}}$ & $3.75 \pm 0.11^{\mathrm{c}}$ & $3.42 \pm 0.08^{\mathrm{b}}$ & 0.137 & 0.001 \\
\hline $\mathbf{6}$ & $2.58 \pm 0.02^{\mathrm{a}}$ & $4.08 \pm 0.15^{\mathrm{c}}$ & $3.67 \pm 0.11^{\mathrm{b}}$ & 0.164 & 0.00 \\
\hline $\begin{array}{c}\text { Overall } \\
\text { mean }\end{array}$ & $2.37 \pm 0.05$ & $3.48 \pm 0.16$ & $3.19 \pm 0.14$ & 0.393 & 0.88 \\
\hline
\end{tabular}

Mean with different superscripts row wise indicate significant difference $(\mathrm{P}<0.01)$

\section{Hip width}

The observed values for hip (HW) width during different fortnights and overall mean were non-significant $(\mathrm{P}>0.05)$ in all fortnights in lambs fed with different experimental diets. Kumar Sandeep et al., (2017) reported the similar results in Deccani sheep in intensive farming system.

\section{Tail length}

The observed values for tail length (TL) were non-significant in all fortnights but linearly increased in all treatment groups. The overall mean and final tail length were also nonsignificantly highest in Moringa supplemented groups compared to control group. The findings in the present study are in agreement with the findings of Kumar Sandeep et al., (2017) and Mahmud (2013). In contrast to the present findings Adegun and Aye (2011) found a significant $(\mathrm{P}<0.05)$ increase in final tail length when sheep was fed with Moringa based multi nutrient blocks.

\section{Fortnightly face length}

Significantly $(\mathrm{P}<0.05)$ higher face length was observed in $\mathrm{T} 2$ group than $\mathrm{T} 1$ group and no significant difference was observed between $\mathrm{T} 2$ and $\mathrm{T} 3$ groups. This could be due to more weight gain along with bony growth as a result of better digestibility and efficient utilization of nutrients in Moringa oleifera based diets. The findings are corroborated with findings of Iqbal et al., (2013) in Deccani sheep.

\section{Body condition score}

Effect of feeding experimental diets on BCS in Deccani lambs is present in Table 3. Body Condition score is practical management tool to be used in conjunction with nutritional and other management strategies to optimize production of the flock.

All the experimental groups have shown a gradual increment in their BCS during experimental period. There was a significant $(\mathrm{P}<0.01)$ increase in BCS during all fortnights. The BCS during $1^{\text {st }}$ and $2^{\text {nd }}$ fortnight was significantly higher in T2 group than $\mathrm{T} 1$ group and similar between T2 and T3 groups. The final mean of BCS had a significant difference $(\mathrm{P}<0.01)$ among the three treatment groups.

The final BCS was significantly $(\mathrm{P}<0.01)$ higher in T2 group than T1 and T3 groups. From the results, it is evident that the overall BCS has improved at the end of the experiment, that indicated the ideal body fat reserves and muscle thickness which was reflection of increases body weight gain in 
respective fortnights. Similar results were reported by Moyo et al., (2012b) when crossbred Xhosa lop eared goats fed with Moringa oleifera Lam. Similarly, Kochewad et al., (2018) reported the significant difference $(\mathrm{P}<0.05)$ in BCS in Deccani lambs reared in intensive farming system.

\section{References}

Adegun, M. K and Aye, P.A. 2011. Evaluation of Moringa oleifera, Gliricidia sepium and Leucaena leucocephala - based multinutrient blocks as feed supplements for sheep in South Western Nigeria. Agric. Biol. J. N. Am. 2(11): 1395-1401.

BAHS. 2012. Basic Husbandry Statistics, Department of Animal Husbandry, Dairying and Fisheries. Government of India.

Bharambe, V.Y and Bhurte, G. 2012. Comparative Growth Performance of Deccani Lambs under Various Rearing Systems in Agro-ecological Conditions of Konkan. Indian Journal of Hill Farming. 25(1):44-47.

Dass, G. 2007. Production performance and management practices of Pugal sheep in the home tract. Ind. J. Anim. Res. 77(8): 763-766.

Duncan, D. B. 1955. Multiple range and multiple F tests. Biometrics. 11: 1-42.

ICAR. Indian Council of Agricultural Research. 2013. Nutrient requirements for Sheep, Goat and Rabbit.

IGFRI. 2013. Indian Grassland and Fodder Research Institute. Vision document 2050.

Iqbal, M., Javed, K. and Ahmad, N. 2013. Prediction of body weight measurements in Beetal Goats. Pakistan Journal of Science. 65(4).

Jagritisrivastav. 2019. Effect of Supplementation of Moringa oleifera Leaves on Nutrient Utilization and
Growth Performance in Goats M.V.Sc. Thesis, Raj. Univ. of Vet and Ani. Sci, Bikaner.

Kochewad, S. A., Raghunandan, T., Kapa Sargan Rao, Kondal Reddy, N., Nalilni and D.B.V. Ramana.2018. Productive performance, body condition score and carcass characteristics of Deccani lambs reared under different farming systems. Ind. J. Anim. Res., B-3478:1-5.

Kumar Sandeep, Dahiya S.P., Malik Z.S and Patil, C.S. 2017. Prediction of body weight from linear body measurements in sheep. Indian J Anim. Res,. DOI: 188051 ijar.B-3360.

Mahmoud. 2013. Effect of feeding on Moringa oleifera stems on productive performance of growing lambs. Egyp. J. Nut. and feed.16 (2):281-292.

Moyo, B., Oyedemi, S., Masika, P.J., Muchenje, V.2012a. Polyphenolic content and antioxidant properties of Moringa oleifera leaf extracts and enzymatic activity of liver from Goats supplemented with Moringa oleifera leaves/sunflower seed cake. Trop. Ani.l Health Prod. . 44: 801- 809.

Moyo, B., Patrick, J. M. and Mu chenje, V. 2012b. Effect of supplementing crossbred Xhosa lop- eared goat castrates with Moringa oleifera leaves on growth performance, carcass and non-carcass characteristics. Trop. Ani.l Health Prod. 44: 801- 809.

Narasimham, S.A.L., Rao G.N., Gupta, B.R., Reddy, C.E and Satyanarayana, A., 2003. A study on body weights and biometrical measurements of Nellore sheep reared under farm conditions. Chiron, 32: 55-59.

Padma Meel. 2018. Effect of feeding drumstick (Moringa oleifera) leaves on Growth Performance in Kids of Sirohi Goat M.V.Sc. Thesis, Raj. Univ. of Vet and Ani. Sci, Bikaner

Pomeroy, R.W. 1955. Progress in the 
physiology of farm Animals. Butterworths scientific publication, London. 2:395-429

Rajanna, N, Mahender ,M., Raghunandan, T and Venkatramana. 2013. A study on body weight and biometry of Nellore Sheep in different agro climatic zone of Telangana region in Andrapradesh. $J$. Research and reviews; J. of Vet. Sci. and Tech, 2(2):1-5.

Russel, A.J.F., Doney, J.M and Gunn, R.G. 1969. Subjective assessment of body fat in live sheep. In: J. Agr. Sci., Camb, 72: 451-454.

Sarwatt, S.V., Milangha, M. S., Lekule, F.P and Madalla, N. 2000. Moringa oleifera and cottonseed cake as supplements for small holder dairy cows fed Napier grass. Liv. Res. for Rural Devel.16 (6).

Snedecor, G, W and Cochran, W. G. 1994. Statistical methods. $8^{\text {th }}$ edition, Iowa State University Press, Ames, Iowa, USA-50010.

\section{How to cite this article:}

Bhokre, S. M., N. Rajanna, D. B. V. Ramana, D. Nagalakshmi, M. Kishan Kumar and Sashi Kumar, M. 2020. Effect of Feeding of Moringa (Moringa Oleifera) Leaf Meal Based Diets on the Biometry and Body Condition Score of Deccani Lambs. Int.J.Curr.Microbiol.App.Sci. 9(04): 1089-1096. doi: https://doi.org/10.20546/ijcmas.2020.904.129 